Prepared in cooperation with the U.S. Environmental Protection Agency

\title{
Compilation of Watershed Models for Tributaries to the Great Lakes, United States, as of 2010, and Identification of Watersheds for Future Modeling for the Great Lakes Restoration Initiative
}

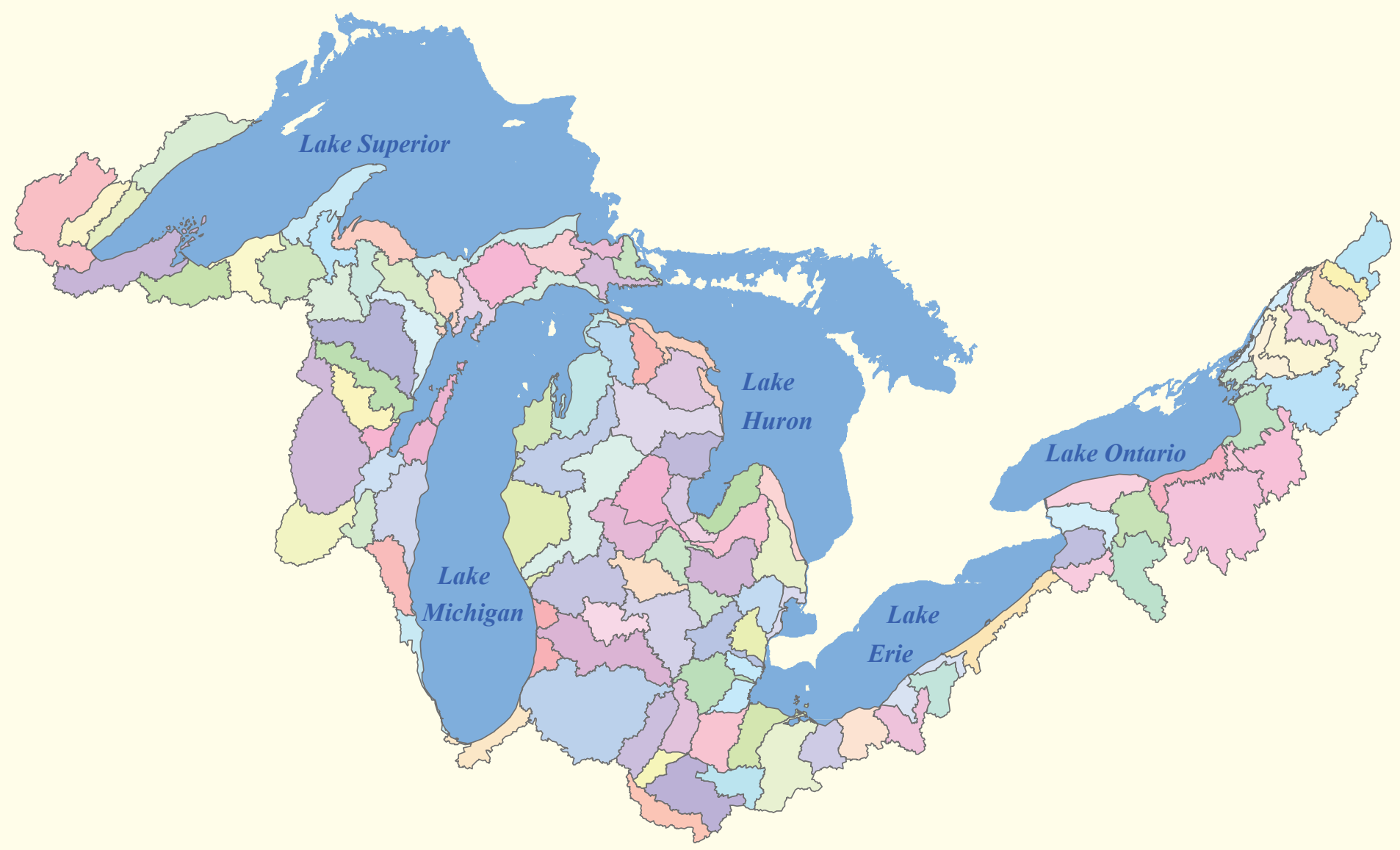

Open-File Report 2011-1202 
Cover. Watershed boundary dataset for Great Lakes Region, accessed July 20, 2011, at http://datagateway.nrcs.usda.gov. 


\section{Compilation of Watershed Models for Tributaries to the Great Lakes, United States, as of 2010, and Identification of Watersheds for Future Modeling for the Great Lakes Restoration Initiative}

By William F. Coon, Elizabeth A. Murphy, David T. Soong, and Jennifer B. Sharpe

Prepared in cooperation with the U.S. Environmental Protection Agency

Open-File Report 2011-1202 


\title{
U.S. Department of the Interior \\ KEN SALAZAR, Secretary \\ U.S. Geological Survey \\ Marcia K. McNutt, Director
}

\author{
U.S. Geological Survey, Reston, Virginia: 2011
}

For more information on the USGS - the Federal source for science about the Earth, its natural and living resources, natural hazards, and the environment, visit http://www.usgs.gov or call 1-888-ASK-USGS.

For an overview of USGS information products, including maps, imagery, and publications, visit http://www.usgs.gov/pubprod

To order this and other USGS information products, visit http://store.usgs.gov

Any use of trade, product, or firm names is for descriptive purposes only and does not imply endorsement by the U.S. Government.

Although this report is in the public domain, permission must be secured from the individual copyright owners to reproduce any copyrighted materials contained within this report.

Suggested citation:

Coon, W.F., Murphy, E.A., Soong, D.T., and Sharpe, J.B., 2011, Compilation of watershed models for tributaries to the Great Lakes, United States, as of 2010, and identification of watersheds for future modeling for the Great Lakes Restoration Initiative: U.S. Geological Survey Open-File Report 2011-1202, 23 p. (Also available at http://pubs. usgs. gov/of/2011/1202.) 


\section{Contents}

Abstract
Introduction
Compilation of Existing Watershed Models
Assessment of Watershed Characteristics
Criteria for Selection of Tributary Watersheds for Future Modeling
Identification of Modeling Software and Candidate Watersheds for Modeling
$\quad$ Kalamazoo River, Michigan
Banawanda Creek, New York
Summary.

\section{Figures}

1. Map showing hydrologic soil groups of the Great Lakes Basin, United States, and three tributary watersheds identified for modeling

2. Map showing land uses and land covers of the Great Lakes Basin, United States, and three tributary watersheds identified for modeling .

3. Map showing surficial deposits of the Great Lakes Basin, United States, and three tributary watersheds identified for modeling..

\section{Tables}

1. Tributaries to the Great Lakes, United States, with existing watershed models, U.S. Environmental Protection Agency Areas of Concern, and (or) U.S. Geological Survey water-quality monitoring sites for the Great Lakes Restoration Initiative, as of 2010

2. Watershed models and selected hydraulic, sediment, and (or) water-quality models for tributaries to the Great Lakes, United States, as of 2010 


\section{Conversion Factors, Datums, and Abbreviations}

\begin{tabular}{ccl}
\hline Multiply & By & \multicolumn{1}{c}{ To obtain } \\
\hline & Length & \\
\hline mile $(\mathrm{mi})$ & 1.609 & kilometer $(\mathrm{km})$ \\
\hline & Area & \\
\hline square mile $\left(\mathrm{mi}^{2}\right)$ & 259.0 & hectare $($ ha) \\
square mile $\left(\mathrm{mi}^{2}\right)$ & 2.590 & square kilometer $\left(\mathrm{km}^{2}\right)$ \\
\hline
\end{tabular}

Vertical coordinate information is referenced to North American Vertical Datum of 1929

(NAVD 29).

Horizontal coordinate information is referenced to the North American Datum of 1983 (NAD 83).

\section{List of Acronyms}

$\begin{array}{ll}\text { AFINCH } & \text { Analysis of Flows In Networks of CHannels } \\ \text { AGNPS } & \text { Agricultural Non-Point Source Pollution } \\ \text { AHPS } & \text { Advanced Hydrologic Prediction Service } \\ \text { AOC } & \text { Area of Concern } \\ \text { BMP } & \text { Best-management practice } \\ \text { CAFO } & \text { Concentrated animal feeding operation } \\ \text { DLBRM } & \text { Distributed Large Basin Runoff Model } \\ \text { GIS } & \text { Geographic information system } \\ \text { GLERL } & \text { Great Lakes Environmental Research Laboratory } \\ \text { GLRI } & \text { Great Lakes Restoration Initiative } \\ \text { HIT } & \text { High Impact Targeting } \\ \text { HSPF } & \text { Hydrological Simulation Program-Fortran } \\ \text { LBRM } & \text { Large Basin Runoff Model } \\ \text { L-THIA } & \text { Long-Term Hydrologic Impact Assessment } \\ \text { NHDPlus } & \text { National Hydrography Dataset Plus } \\ \text { NOAA } & \text { National Oceanic and Atmospheric Administration } \\ \text { NWS } & \text { National Weather Service } \\ \text { PCB } & \text { Polychlorinated biphenyl } \\ \text { PRMS } & \text { Precipitation-Runoff Modeling System } \\ \text { RFC } & \text { River Forecast Center } \\ \text { SAC-SMA } & \text { Sacramento Soil Moisture Accounting } \\ \text { SPARROW } & \text { SPAtially Referenced Regressions on Watershed attributes }\end{array}$




$\begin{array}{ll}\text { SWAT } & \text { Soil and Water Assessment Tool } \\ \text { TMDL } & \text { Total maximum daily load } \\ \text { USACE } & \text { U.S. Army Corps of Engineers } \\ \text { USEPA } & \text { U.S. Environmental Protection Agency } \\ \text { USGS } & \text { U.S. Geological Survey } \\ \text { WATER } & \text { Water Availability Tool for Environmental Resources } \\ \text { WEPP } & \text { Water Erosion Prediction Project } \\ \text { WWTP } & \text { Wastewater-treatment plant }\end{array}$


This page has been left blank intentionally. 


\title{
Compilation of Watershed Models for Tributaries to the Great Lakes, United States, as of 2010, and Identification of Watersheds for Future Modeling for the Great Lakes Restoration Initiative
}

\author{
By William F. Coon, Elizabeth A. Murphy, David T. Soong, and Jennifer B. Sharpe
}

\begin{abstract}
As part of the Great Lakes Restoration Initiative (GLRI) during 2009-10, the U.S. Geological Survey (USGS) compiled a list of existing watershed models that had been created for tributaries within the United States that drain to the Great Lakes. Established Federal programs that are overseen by the National Oceanic and Atmospheric Administration (NOAA) and the U.S. Army Corps of Engineers (USACE) are responsible for most of the existing watershed models for specific tributaries. The NOAA Great Lakes Environmental Research Laboratory (GLERL) uses the Large Basin Runoff Model to provide data for the management of water levels in the Great Lakes by estimating United States and Canadian inflows to the Great Lakes from 121 large watersheds. GLERL also simulates streamflows in 34 U.S. watersheds by a gridbased model, the Distributed Large Basin Runoff Model. The NOAA National Weather Service uses the Sacramento Soil Moisture Accounting model to predict flows at river forecast sites. The USACE created or funded the creation of models for at least 30 tributaries to the Great Lakes to better understand sediment erosion, transport, and aggradation processes that affect Federal navigation channels and harbors. Many of the USACE hydrologic models have been coupled with hydrodynamic and sediment-transport models that simulate the processes in the stream and harbor near the mouth of the modeled tributary.

Some models either have been applied or have the capability of being applied across the entire Great Lakes Basin; they are (1) the SPAtially Referenced Regressions On Watershed attributes (SPARROW) model, which was developed by the USGS; (2) the High Impact Targeting (HIT) and Digital Watershed models, which were developed by the Institute of Water Research at Michigan State University; (3) the Long-Term Hydrologic Impact Assessment (L-THIA) model, which was developed by researchers at Purdue University; and (4) the Water Erosion Prediction Project
\end{abstract}

(WEPP) model, which was developed by the National Soil Erosion Research Laboratory of the U.S. Department of Agriculture. During 2010, the USGS used the PrecipitationRunoff Modeling System (PRMS) to create a hydrologic model for the Lake Michigan Basin to assess the probable effects of climate change on future groundwater and surface-water resources. The Water Availability Tool for Environmental Resources (WATER) model and the Analysis of Flows In Networks of CHannels (AFINCH) program also were used to support USGS GLRI projects that required estimates of streamflows throughout the Great Lakes Basin.

This information on existing watershed models, along with an assessment of geologic, soils, and land-use data across the Great Lakes Basin and the identification of problems that exist in selected tributary watersheds that could be addressed by a watershed model, was used to identify three watersheds in the Great Lakes Basin for future modeling by the USGS. These watersheds are the Kalamazoo River Basin in Michigan, the Tonawanda Creek Basin in New York, and the Bad River Basin in Wisconsin. These candidate watersheds have hydrogeologic, land-type, and soil characteristics that make them distinct from each other, but that are representative of other tributary watersheds within the Great Lakes Basin. These similarities in the characteristics among nearby watersheds will enhance the usefulness of a model by improving the likelihood that parameter values from a previously modeled watershed could reliably be used in the creation of a model of another watershed in the same region. The software program Hydrological Simulation Program-Fortran (HSPF) was selected to simulate the hydrologic, sedimentary, and water-quality processes in these selected watersheds. HSPF is a versatile, process-based, continuous-simulation model that has been used extensively by the scientific community, has the ongoing technical support of the U.S. Environmental Protection Agency and USGS, and provides a means to evaluate the effects that land-use changes or management practices might have on the simulated processes. 


\section{Introduction}

The Great Lakes Restoration Initiative (GLRI) (White House Council on Environmental Quality and others, 2010) identified five major focus areas to improve the water quality and aquatic habitat of the Great Lakes: (1) toxic substances in water and sediment; (2) invasive aquatic species; (3) degradation of nearshore habitat owing, at least partly, to nonpoint-source contamination from tributary inflows; (4) loss and degradation of terrestrial and aquatic habitats, especially coastal wetlands, and the associated negative effects on native species; and (5) inadequate monitoring of ecosystem health, assessment of restoration progress, and coordination of efforts among Great Lakes' stakeholders. The U.S. Geological Survey (USGS), in cooperation with the U.S. Environmental Protection Agency (USEPA), began at least 25 projects during 2009-10 to address these issues (U.S. Geological Survey, 2010a). Among these projects were several that required understanding of the hydrologic and water-quality processes within the watersheds of many tributaries that drain to the Great Lakes. GLRI objectives can be supported by the estimation of tributary flows, water temperatures, and nonpoint-source loads of sediment and nutrients, the assessment of their effects on aquatic habitats, and identification of the probable improvements to ecosystem health and functions by mitigation of these effects.

Precipitation-runoff watershed models, which are valuable tools used to understand hydrologic processes and to guide water-resources managers in making decisions on water-related issues, are a means by which all of these GLRI objectives can be addressed. In addition, output from a watershed model can be used to identify subbasins that generate disproportionately large loads of sediment or nutrients; watershed managers can then target these subbasins for mitigation measures. Scenarios that reflect future landuse changes or management practices in a watershed can be simulated, and their probable effects on streamflows and water-quality loads can be assessed. Similarly, reconstructed meteorological data that reflect anticipated changes in climate can be simulated by a watershed model, and probable changes in the magnitude and frequency of peak and low flows and in sediment and nutrient loads can be noted. Watershed managers can then assess climate-change effects on transportation infrastructure and aquatic biota and habitat.

Watershed models of tributaries throughout the Great Lakes Basin have been created with different software programs and for different purposes. In 2009, surface-water modelers of the USGS were charged with creating watershed models for up to three Great Lakes tributaries in the United States where identifiable water-related problems could be addressed using this approach. The first step in this project was to compile a list of existing watershed models. To that end, Federal and state agencies, consulting firms, and academic institutions were contacted to identify (1) existing models for that part of the Great Lakes Basin within the United States, (2) the application or purpose for which the model was created, and (3) the modeling software used. The second step was to assess the regional characteristics-hydrogeology, land use, land cover, and soils - of the Great Lakes Basin and to use this information to identify candidate watersheds for modeling that would be representative of a large region of the Great Lakes Basin. This assessment step would enhance the usefulness of a model by improving the likelihood that parameter values from a modeled watershed could reliably be transferred to, and used in, the creation of a model of another watershed with similar hydrogeologic, land-type, and soil characteristics. The third step was to identify a public-domain modeling software that had the potential to meet the objectives of the GLRI.

This report presents a compilation of known watershed models and other modeling tools that have been developed for, or applied to, tributaries throughout that part of the Great Lakes Basin within the United States as of 2010. On the basis of regional characteristics - hydrogeology, land-type, and soils - and other selection criteria, three watersheds - the Kalamazoo River in Michigan (Mich.), Tonawanda Creek in New York, and the Bad River in Wisconsin (Wis.) are identified for future modeling. Problems and distinct characteristics that qualify these watersheds for modeling are presented.

\section{Compilation of Existing Watershed Models}

Watershed models have been created for many of the United States tributaries in the Great Lakes Basin. The tributaries for which a model exists, as well as those that are considered Areas of Concern by the U.S. Environmental Protection Agency (USEPA, 2010) or that have some component of water-quality monitoring as part of the GLRI by the USGS are listed in table 1 (at back of report). In a few cases - for example, the Fox River (Wis.), Saginaw River (Mich.), St. Joseph River (Mich. and Indiana), and Maumee River (Ohio) - several models have been created for a given watershed, as well as for particular subbasins within the larger watershed. At least 17 different types of modeling software, ranging from complex numerical models to interactive geospatial-analytical tools, have been used to simulate the hydrology and, in many cases, sediment and nutrient processes, of tributaries to the Great Lakes (table 2, at back of report). The purposes for which the models were created vary widely and include simulation of sediment processes, estimation of nutrient loads, assessment of best-management practices (BMPs), and calculation of total maximum daily loads (TMDLs).

Several modeling tools have been developed that are applicable to the entire Great Lakes Basin. Among these is the Large Basin Runoff Model (LBRM) (Croley, 1982), a physically based, lumped-parameter model, which was developed by the National Oceanic and Atmospheric 
Administration (NOAA), Great Lakes Environmental Research Laboratory (GLERL) to simulate rainfall-runoff relations for 121 large watersheds surrounding the Great Lakes (National Oceanic and Atmospheric Administration, 2009a). NOAA, which is concerned with providing data for the management of water levels in the Great Lakes for purposes of flood control, navigation, and hydropower, requires a method of estimating tributary inflows to the Great Lakes. The LBRM models are run daily to provide estimates of United States and Canadian inflows to each Great Lake. Streamflows in 34 United States watersheds (tables 1 and 2, at back of report) have been simulated by a spatially distributed, two-dimensional, grid-based model, the Distributed Large Basin Runoff Model (DLBRM) (National Oceanic and Atmospheric Administration, 2009b). Enhancements to these DLBRM models by collaboration among NOAA-GLERL and researchers at several academic institutions through the Cooperative Institute for Limnology and Ecosystems Research will incorporate simulation of sediment and nutrient transport and change the simulation time step from daily to hourly (National Oceanic and Atmospheric Administration, 2010).

During 2010, as part of the GLRI, the USGS began creation of a hydrologic model for the Lake Michigan Basin using the Precipitation-Runoff Modeling System (PRMS) (Leavesley and others, 1983; U.S. Geological Survey, 2011a). The model will be used to simulate inflows to Lake Michigan and to assess the probable effects of climate change on future groundwater and surface-water resources (Hunt, 2010). The USGS also has developed a SPAtially Referenced Regressions On Watershed attributes model (SPARROW) (Schwarz and others, 2006; Preston and others, 2009; U.S. Geological Survey, 2010b) to (1) estimate long-term average annual loads of nutrients that enter the Great Lakes from their tributaries, (2) describe the distribution of nutrient loading and the factors affecting this distribution throughout the Great Lakes Basin, and (3) rank the tributaries on the basis of their relative yields of nutrients (Robertson and Saad, 2011). The SPARROW model will be coupled with water-quantity models to predict probable changes in nutrient loading as a result of future climatic conditions. The resultant model, referred to as HydroSPARROW, will be linked with streamflow estimates (1) from PRMS (Hunt, 2010) to predict changes in nutrient loading to Lake Michigan and (2) from the Water Availability Tool for Environmental Resources (WATER) (Williamson and others, 2009; U.S. Geological Survey, 2011b) to predict changes in nutrient loading throughout the Great Lakes Basin. HydroSPARROW also will be used to assess the effects of land-use changes on nutrient loads.

Another USGS GLRI project (Reeves, 2010) is designed to generate a unified stream classification system that will link landscape, hydrologic, and biologic information to stream networks within the framework of the National Hydrography Dataset Plus (NHDPlus) (U.S. Environmental Protection Agency, 2011a). To help assess the effects that hydrologic alterations, which result from changes in land use or climate conditions, are likely to have on aquatic ecosystems, a hydrologic dataset that provides consistent estimates of streamflows across the entire Great Lakes Basin is required. To that end, the program, Analysis of Flows In Networks of CHannels (AFINCH) (Holtschlag, 2009), is being used to estimate time series of monthly streamflows for reaches in gaged and ungaged watersheds in the Great Lakes Basin. These flows, as well as water yields, will be added to attribute tables for stream segments and their associated catchments as defined in NHDPlus.

The High Impact Targeting (HIT) model, which was developed by the Institute of Water Research (2011a) at Michigan State University, couples the revised universal soilloss equation (Renard and others, 1997 ) and a geographic information system (GIS), Digital Watershed (Institute of Water Research, 2011b), to identify areas susceptible to erosion, estimate soil losses from agricultural areas, and assess BMPs. An interactive application of the HIT model provides these capabilities for the Great Lakes Basin (Institute of Water Research, 2011c). The Long-Term Hydrologic Impact Assessment (L-THIA) model, developed by researchers at Purdue University (2011), uses runoff estimated by the Natural Resources Conservation Service TR-55 method (U.S. Department of Agriculture, 1986) and event mean concentrations that are based on land uses to estimate longterm average annual recharge, runoff, and contaminant loads in urban areas. An interactive application of the L-THIA model provides these data for most of the states in the Great Lakes Basin (Purdue University, 2011). L-THIA also can be used to assess the water-quality effects of land-use changes and BMPs. The Water Erosion Prediction Project (WEPP) model is a process-based, distributed-parameter, erosionprediction model that was developed by the National Soil Erosion Research Laboratory of the U.S. Department of Agriculture, Agricultural Research Service (U.S. Department of Agriculture, 2010). The WEPP model can be used to estimate long-term sediment yields from cropland, rangeland, and disturbed forest sites for hillslope applications or small watersheds. An online site on a public server hosted at Washington State University (2011) has been established for application of WEPP throughout the Great Lakes Basin.

The NOAA National Weather Service (NWS) has compiled a suite of rainfall-runoff, hydraulic, and flowrouting models that are used by River Forecast Centers (RFC) (National Weather Service, 2011a) to estimate near future runoff and predict water levels at river forecast sites. The three RFCs - North Central (Minnesota), Ohio, and Northeast (Massachusetts) - that make runoff predictions for the drainage area of the Great Lakes use the Sacramento Soil Moisture Accounting (SAC-SMA) model (Burnash, 1995) and SNOW-17 (Anderson, 2006), a snow accumulation and ablation model, to estimate runoff and snow melt, respectively. These forecasts are made for streams at USGS streamgage stations with drainage areas greater than about 75 square miles $\left(\mathrm{mi}^{2}\right)$ so that timely predictions can be made at a 6-hour simulation time step. Because predictions are made for hundreds of sites in the Great Lakes Basin and a given stream, 
including its tributaries, can have multiple forecast sites, these streams are not included in tables 1 and 2. These forecast sites can be identified at the NWS Advanced Hydrologic Prediction Service (AHPS) website (National Weather Service, 2011b).

Most of the remaining known watershed models that have been created for specific tributaries in the Great Lakes Basin were created by or for the U.S. Army Corps of Engineers (USACE; table 2). The USACE has been charged with the responsibility of maintaining Federal navigation channels and harbors (U.S. Army Corps of Engineers, 2010). Because sediment aggradation is a major problem that interferes with harbor operations, and to better understand sediment erosion, transport, and aggradation processes, the USACE, under Section 516(e) of the Water Resources Development Act (U.S. Congress, 1996), has been authorized to develop, or fund the development of, models to simulate sediment processes in tributaries that drain to the Federal harbors (U.S. Army Corps of Engineers, 2005, 2006; Great Lakes Commission, 2009). To date (2010), 30 tributary watersheds have been modeled for this purpose; models for several more watersheds are being created. The watershed-wide sediment models can be used to assess mitigative measures that will decrease the loading of sediment and contaminants to tributaries and thereby decrease the need for, and costs of, dredging the navigation channels. A wide variety of modeling software has been used in different watersheds to best address the specific issues and provide the desired outputs for a given watershed. The Soil and Water Assessment Tool (SWAT) (U.S. Department of Agriculture, 2011a) was used to model most of the tributary watersheds, but the Hydrological Simulation Program-Fortran (HSPF) model (Bicknell and others, 2001) and the Agricultural NonPoint Source Pollution (AGNPS) model (U.S. Department of Agriculture, 2011b) also were used. All three of these models are physically based, spatially distributed, and capable of simulating sediment and nutrient processes. AGNPS is an event-based model that primarily is used in watersheds dominated by agricultural uses. SWAT and HSPF are continuoussimulation models, and although HSPF can be applied in a watershed with any combination of land uses, SWAT often is used in watersheds dominated by rural land uses only. Many of the USACE watershed models were coupled with hydrodynamic and sediment-transport models to assess, in detail, the processes in the stream and harbor near the mouths of modeled tributaries. These ancillary models are included in table 2 . Those tributaries for which hydrodynamic and sedimenttransport models were created without a watershed model to simulate sediment loads to stream channels are not included in table 2.

Excluding the models that have been applied across the entire Great Lakes Basin, one or more models have been created for at least 72 individual tributary watersheds. The most commonly used modeling software includes SWAT, DLBRM, HSPF, and L-THIA.

\section{Assessment of Watershed Characteristics}

By identifying those tributary watersheds in the Great Lakes Basin for which models exist, the compilation of watershed models consequently identified those watersheds that have not been modeled or have models that do not adequately address GLRI objectives. These watersheds could be considered as candidates for modeling in the future. The second step toward identification of candidate tributary watersheds for modeling was the assessment of watershed characteristics that strongly affect the hydrologic and water-quality processes in a watershed. The intent of this assessment was to identify distinct regional characteristics that are applicable to large areas of the Great Lakes Basin, such as the Lower Peninsula of Michigan or the area south of Lake Superior. Then a watershed within a given region could be selected for modeling with the increased likelihood that parameter values used for the modeled watershed could be transferred to, and used in, a model for another watershed within the same region. To that end, GIS coverages were created for soil characteristics (hydrologic soil group), landuse and land-cover types, and geological characteristics, such as surficial deposits (figs. 1, 2, and 3, at back of report).

\section{Criteria for Selection of Tributary Watersheds for Future Modeling}

Candidate watersheds for modeling were assessed on the basis of the following criteria:

- lack of an existing watershed model or a watershed model that with upgrades or modifications could serve the same purposes as a new model;

- problems in the watershed, including flooding, sediment erosion and aggradation, and water quality, that could be addressed by a watershed model;

- tributary is in a USEPA (2010) Area of Concern (AOC) or drains to a Federal navigation harbor;

- dominant land uses-land covers and soil types;

- regional bedrock and surficial geological characteristics;

- availability of flow data from USGS streamgages for model calibration;

- existence and availability of water-quality data for model calibration;

- presence of a USGS GLRI water-quality monitoring station in the watershed; and

- existence of a watershed association of concerned stakeholders that would be interested in using the model for watershed management and decision making. 


\section{Identification of Modeling Software and Candidate Watersheds for Modeling}

Several watershed modeling programs were assessed for their capabilities to meet the multiple objectives of the GLRI. A public-domain, process-based, continuous-simulation model that was capable of simulating the hydrologic, sedimentary, and water-quality processes in a watershed and providing a means for evaluating the effects that land-use changes or management practices might have on these processes was desirable. The program HSPF (Donigian and others, 1995) was selected to model the candidate watersheds for these reasons. Although HSPF is a data-intensive model, it is supported by USEPA and USGS and has been used extensively and for various applications by the scientific community. HSPF enables scenario development for the analysis of the probable effects of land-use changes, BMPs, and climate change.

Using the selection criteria listed in the previous section, three watersheds were selected as potential candidates for watershed modeling - the Kalamazoo River in Michigan (a tributary to Lake Michigan), Tonawanda Creek in New York (a tributary to the Niagara River and Lake Ontario), and the Bad River in Wisconsin (a tributary to Lake Superior; fig. 1). These watersheds exhibited geologic, soil, and landtype characteristics that make them distinct from each other but representative of a large region of the Great Lakes Basin that encompasses other tributary watersheds that share these characteristics. The candidate watersheds also have water-quality problems that impede progress toward the GLRI objective to improve the water quality and the aquatic habitat of the Great Lakes. Stakeholders in each watershed would benefit from a model that could estimate flows, water temperatures, and nonpoint-source loads of sediment and nutrients. The candidate watersheds are described below.

\section{Kalamazoo River, Michigan}

- The Kalamazoo River Basin has been modeled by NOAA with DLBRM and by Kieser and Associates (2011) with the L-THIA model. DLBRM is a process-based, distributed model capable of simulating streamflows on a daily basis, but in its present form, it cannot simulate sediment and nutrient processes as can HSPF. L-THIA is a quick and accessible model for estimating long-term average annual runoff and nutrient loads in order to evaluate the effects of land-use changes. Unlike HSPF, L-THIA cannot simulate watershed processes at daily or hourly time steps, nor is L-THIA output calibrated to observed data from streamflow and water-quality monitoring sites.
- The 80-mile (mi) reach from Morrow Dam, just east of Kalamazoo, to Lake Michigan is a USEPA AOC because river sediments are contaminated with polychlorinated biphenyls (PCBs) that originated from paper industry de-inking processes prior to the mid-1970s (U.S. Environmental Protection Agency, 2011b).

- Besides the ecological degradation that has resulted from PCB contamination, other problems in the watershed include agricultural and urban nonpoint sources, concentrated animal feeding operations (CAFOs), and industrial and wastewater-treatment-plant (WWTP) discharges. Also, the river and its tributaries have many dams that are being considered for removal, which could cause new problems from resuspension of trapped sediments.

- The drainage area of the watershed is $2,020 \mathrm{mi}^{2}$, 45 percent of which is used for agriculture (cultivated crops and pasture-hay); 41 percent is forested or open rural areas (Kieser and Associates, 2001). Large urban areas are found along the Kalamazoo River corridor.

- The watershed's surficial deposits are dominated by sand and sandy and loamy till.

- The watershed characteristics are representative of those found in a large part of the Lower Peninsula of Michigan.

- There are 10 USGS streamgages that monitor streamflow in the watershed. Water quality (nutrients, major ions, physical characteristics, and mercury) has been monitored at various sites in the watershed by the Michigan Department of Environmental Quality. As part of the GLRI water-quality monitoring program, the USGS site at New Richmond was upgraded from a streamflow-monitoring gage to a long-term water-quality sampling site for sediment and nutrients. Two samplesone water and one bed sediment-also were collected and analyzed for pesticides, pharmaceuticals, personalcare products, wastewater-indicator compounds, organic compounds, and PCBs.

- Detailed hydraulic data are available from a recent USGS flood-inundation mapping project for the 15-mi reach from Marshall to Battle Creek (Hoard and others, 2010). A less detailed data set that covers the reach from Marshall to the river's mouth also is available (C.M. Rachol, U.S. Geological Survey, written commun., 2010).

- The Kalamazoo River Watershed Council works collaboratively with the community, government agencies, local officials, and businesses to improve and protect the health of the Kalamazoo River, its tributaries, and its watershed (Kalamazoo River Watershed Council, 2011). 


\section{Tonawanda Creek, New York}

- There is no known watershed model of the Tonawanda Creek Basin.

- Problems in the watershed include agricultural nonpoint sources, CAFO point sources, sewage and WWTP discharges, erosion and sedimentation, flooding, habitat degradation, and the effects of future development. The creek is the source of drinking water for the City of Batavia.

- The watershed has a drainage area of $658 \mathrm{mi}^{2}$, which is dominated by agricultural uses ( 45 percent), forested areas (27 percent), and wetlands (11 percent) (Tonawanda Creek Watershed Committee, 2011).

- The surficial deposits of the watershed are mainly loamy and clayey till.

- The watershed characteristics are representative of those found along the northeastern shore of Lake Erie and the southern shore of Lake Ontario.

- Streamflow is monitored at four USGS streamgages in the watershed. Some water-quality monitoring of nutrients and suspended solids is conducted by Soil and Water Conservation Districts. A water sample was collected from Tonawanda Creek at Rapids for the GLRI water-quality monitoring program and was analyzed for pesticides, pharmaceuticals, personal-care products, wastewaterindicator compounds, organic compounds, and PCBs.

- The Tonawanda Creek Watershed Committee represents a diverse collection of Federal, state, and local agencies, the Tonawanda Seneca Indian Nation, and concerned individuals and citizen groups.

- Great interest has been expressed by the USACE (Byron Rupp, U.S. Army Corps of Engineers, oral commun., 2010) for a watershed model that can simulate sediment processes in the Tonawanda Creek Basin.

\section{Bad River, Wisconsin}

- There is no known watershed model of the Bad River Basin.

- Problems that exist in the watershed include nonpointnutrient generation and transport, municipal wastewater discharges, erosion and sedimentation, contaminants (copper, zinc, and sulfate) associated with iron-ore mining, flooding, and aquatic-habitat degradation.

- The drainage area of the watershed is $1,061 \mathrm{mi}^{2}$ and is dominated by forested land (79 percent); a large percentage (16 percent) of the watershed is covered by wetlands (Bad River Watershed Association, 2011).
- The surficial deposits of the upper watershed are loamy till; that of the lower watershed are clayey till.

- The watershed characteristics are representative of those found along the western part of the southern and northern shores of Lake Superior.

- Streamflow is monitored at one site on the Bad River near Odanah and at one site on its tributary, the White River near Ashland. Water-quality data are sparse, but the Bad River Watershed Association collects water samples at many sites in the watershed; samples are analyzed for nutrients, dissolved oxygen, and chloride. As part of the GLRI water-quality monitoring program, the USGS site at Odanah was upgraded from a streamflow-monitoring gage to a long-term water-quality monitoring site for sediment and nutrients. In addition, a water sample was collected and analyzed for pesticides, pharmaceuticals, personalcare products, wastewater-indicator compounds, organic compounds, and PCBs.

- The Bad River Watershed Association is a community organization that works to involve citizens in watershed activities. Other groups and agencies, including the Bad River Tribe, the Natural Resources Conservation Service, and the U.S. Forest Service, are also involved in watershed activities.

\section{Summary}

As part of the Great Lakes Restoration Initiative (GLRI) during 2009-10, the U.S. Geological Survey (USGS) proposed the creation of watershed models for up to three Great Lakes tributaries where identifiable water-related problems could be addressed using such a tool. To that end, the USGS first compiled a list of existing watershed models that had been created for United States tributaries to the Great Lakes. At least 17 different types of modeling software have been used to simulate the hydrologic processes in watersheds of tributaries to the Great Lakes. Most of the watershed models were created to meet program needs of the National Oceanic and Atmospheric Administration (NOAA) and the U.S. Army Corps of Engineers (USACE). The NOAA Great Lakes Environmental Research Laboratory uses the Large Basin Runoff Model to provide data for the management of the water levels in the Great Lakes by estimating United States and Canadian inflows to the Great Lakes from 121 watersheds. The NOAA National Weather Service uses the Sacramento Soil Moisture Accounting model to predict flows at river forecast sites. The USACE created or funded the creation of models for at least 30 tributaries to the Great Lakes to better understand sediment erosion, transport, and aggradation processes that affect Federal navigation channels and harbors. Many of the USACE hydrologic models have been coupled with hydrodynamic and sediment-transport models that 
simulate the processes in the stream and (or) harbor near the mouth of the modeled tributary.

Some models either have been applied or have the capability of being applied across the entire Great Lakes Basin; they are the SPAtially Referenced Regressions On Watershed attributes (SPARROW) model, which was developed by the USGS; the High Impact Targeting (HIT) model and Digital Watershed geographic information system, which were developed by the Institute of Water Research at Michigan State University; the Long-Term Hydrologic Impact Assessment (L-THIA) model, which was developed by researchers at Purdue University; and the Water Erosion Prediction Project (WEPP) model, which was developed by the National Soil Erosion Research Laboratory of the U.S. Department of Agriculture. During 2010, the USGS used the Precipitation-Runoff Modeling System (PRMS) to create a hydrologic model for the Lake Michigan Basin to assess the probable effects of climate change on future groundwater and surface-water resources. Estimated flows generated by the PRMS model and by a Water Availability Tool for Environmental Resources (WATER) model will be linked with nutrient outputs from the USGS SPARROW model to assess the effects that future climate changes might have on nutrient loadings to Lake Michigan and throughout the Great Lakes Basin, respectively. The Analysis of Flows In Networks of CHannels (AFINCH) program was used to support a USGS GLRI project that required estimates of streamflows throughout the Great Lakes Basin to assess the effects that hydrologic alterations resulting from changes in land use or climate conditions might have on aquatic ecosystems.

After compilation of existing watershed models, the next step toward identification of tributary watersheds for modeling was the analysis of geospatial data to identify regional characteristics, including hydrologic soil groups, land-use and land-cover types, and geological characteristics, that were distinct among the regions but applicable to a large area of the Great Lakes Basin. On the basis of this analysis, a watershed within a given region could be selected for modeling with the increased likelihood that parameter values used for the modeled watershed could be transferred to and used in a model for a nearby watershed with similar characteristics. A list of criteria for watershed selection, which includes problems that could be addressed by a watershed model, the existence of streamflow and water-quality data that could be used for model calibration, and the existence of an active watershed association of concerned stakeholders that would be interested in using the model for watershed management and decision making, was generated. Three watersheds in the Great Lakes Basin were identified for future modeling as part of the USGS involvement in the GLRI - the Kalamazoo River Basin in Michigan, the Tonawanda Creek Basin in New York, and the Bad River Basin in Wisconsin. The software program Hydrological Simulation Program-Fortran (HSPF) was selected to simulate the hydrologic, sedimentary, and water-quality processes in these selected watersheds. HSPF is a process-based, continuous-simulation model that provides a means to evaluate the effects that land-use changes or management practices might have on these processes. The versatility of HSPF, its extensive use by the scientific community, and the ongoing technical support provided by USEPA and USGS also are factors in favor of selecting HSPF for future watershed modeling.

\section{References Cited}

Anderson, Eric, 2006, Snow accumulation and ablation model-SNOW-17: National Weather Service, Office of Hydrologic Development, accessed June 2, 2011, at http:// www.nws.noaa.gov/oh/hrl/nwsrfs/users_manual/part2/_ pdf/22snow17.pdf.

Bad River Watershed Association, 2011, Background information, Bad River Watershed Association: Bad River Watershed Association, accessed April 25, 2011, at http://learnscape.org/brwa/index.php?option=com frontpage \&Itemid $=1$.

Bicknell, B.R., Imhoff, J.C., Kittle, J.L., Jr., Jobes, T.H., and Donigian, A.S., Jr., 2001, Hydrological Simulation Program-Fortran, user's manual for version 12: Athens, Ga., U.S. Environmental Protection Agency, 873 p., accessed April 15, 2005, at http://www.epa.gov/docs/ostwater/ BASINS/bsnsdocs.html\#hspf.

Burnash, R.J.C., 1995, The NWS river forecast systemCatchment modeling, in Singh, V.P., ed., Computer models of watershed hydrology: Highlands Ranch, Colo., Water Resources Publications, p. 311-366.

Croley, T.E., II, 1982, Great Lakes Basins runoff modeling: Great Lakes Environmental Research Laboratory, National Oceanic and Atmospheric Administration Technical Memorandum ERL GLERL-39, 96 p., accessed December 2, 2010, at ftp://ftp.glerl.noaa.gov/publications/tech_reports/ glerl-039/tm-039.pdf.

Donigian, A.S., Jr., Bicknell, B.R., and Imhoff, J.C., 1995, Hydrological simulation program-Fortran (HSPF), in Singh, V.P., ed., Computer models of watershed hydrology: Highlands Ranch, Colo., Water Resources Publications, p. 395-442.

Great Lakes Commission, 2009, Great Lakes tributary modeling program: Great Lakes Commission, accessed September 10, 2009, at http://www.glc.org/tributary/.

Hoard, C.J., Fowler, K.K., Kim, M.H., Menke, C.D., Morlock, S.E., Peppler, M.C., Rachol, C.M., and Whitehead, M.T., 2010, Flood-inundation maps for a 15-mile reach of the Kalamazoo River from Marshall to Battle Creek, Michigan: U.S. Geological Survey Scientific Investigations Map 3135, 6 p. pamphlet, 6 sheets, scale 1:100,000. 
Holtschlag, D.J., 2009, Application guide for AFINCH (analysis of flows in networks of channels) described by NHDPlus: U.S. Geological Survey Scientific Investigations Report 2009-5188, 106 p. (Also available at http://pubs. usgs.gov/sir/2009/5188/pdf/sir20095188.pdf.)

Hunt, Randy, 2010, Forecasting Great Lakes Basin responses to future change: U.S. Geological Survey, Great Lakes Restoration Initiative, accessed November 15, 2010, at http://cida.usgs.gov/glri/projects/accountability/responses_ future_change.html.

Institute of Water Research, 2011a, HIT-High impact targeting: Institute of Water Research, Michigan State University, accessed February 1, 2011, at http://www.iwr. msu.edu/hit/.

Institute of Water Research, 2011b, Digital watershed: Institute of Water Research, Michigan State University, accessed February 1, 2011, at http://www.iwr.msu.edu/dw/.

Institute of Water Research, 2011c, HIT (High impact targeting) - A tool for optimizing sedimentation reduction efforts in the Great Lakes Basin: Institute of Water Research, Michigan State University, accessed May 20, 2011, at http://35.9.116.206/hit2/home.htm.

Kalamazoo River Watershed Council, 2011, Partnership agreement: Kalamazoo River Watershed Council, accessed April 25, 2011, at http://www.kalamazooriver.org//content/ view/38/51/.

Kieser and Associates, 2001, Non-point source modeling of phosphorus loads in the Kalamazoo River/ Lake Allegan watershed for a total maximum daily load: Kieser and Associates, 59 p., accessed April 25, 2011, at http://www. kalamazooriver.net/tmdl/docs/Final\%20Report.pdf.

Kieser and Associates, 2011, Watershed and lake management—Kalamazoo River watershed modeling and build-out analysis: Kieser and Associates, accessed April 22, 2011, at http://kieser-associates.com/inside. php?a=PG:590.

Leavesley, G.H., Lichty, R.W., Troutman, B.M., and Saindon, L.G., 1983, Precipitation-runoff modeling systemUser's manual: U.S. Geological Survey Water-Resources Investigations Report 83-4238, 207 p.

National Oceanic and Atmospheric Administration, 2009a, Large basin runoff model (LBRM): Great Lakes Environmental Research Laboratory, accessed September 11, 2009, at http://www.glerl.noaa.gov/res/Programs/pep/ dlbrm/lbrm.html.
National Oceanic and Atmospheric Administration, 2009b, Distributed large basin runoff model: Great Lakes Environmental Research Laboratory, accessed September 11, 2009, at http://www.glerl.noaa.gov/res/Programs/pep/ dlbrm/dlbrm.html.

National Oceanic and Atmospheric Administration, 2010, Next generation large basin runoff models: Great Lakes Environmental Research Laboratory, accessed July 16, 2010, at http://www.glerl.noaa.gov/res/Task_rpts/2000/ wrcroley05-6.html.

National Weather Service, 2011a, River forecast centers: National Weather Service, accessed May 26, 2011, at http:// water.weather.gov/ahps/rfc/rfc.php.

National Weather Service, 2011b, Advanced hydrologic prediction service: National Weather Service, accessed May 26, 2011, at http://water.weather.gov/ahps/.

Preston, S.D., Alexander, R.B., Woodside, M.D., and Hamilton, P.A., 2009, SPARROW MODELINGEnhancing understanding of the Nation's water quality: U.S. Geological Survey Fact Sheet 2009-3019, 6 p. (Also available at http://pubs.usgs.gov/fs/2009/3019/pdf/ fs_2009_3019.pdf.)

Purdue University, 2011, Impacts of land use change on water resources: Long-term hydrologic impact analysis (L-THIA): College of Engineering, Purdue University, accessed February 1, 2011, at https://engineering.purdue. edu/ lthia/.

Reeves, H.W., 2010, Watershed modeling for stream ecosystem management: U.S. Geological Survey, Great Lakes Restoration Initiative, accessed November 15, 2010, at http://cida.usgs.gov/glri/projects/accountability/ watershed_modeling.html.

Renard, K.G., Foster, G.R., Weesies, G.A., McCool, D.K., Yoder, D.C., 1997, Predicting soil erosion by water-A guide to conservation planning with the Revised Universal Soil Loss Equation (RUSLE): United States Department of Agriculture, Agricultural Research Service, Agricultural Handbook No. 703, 385 p., accessed March 15, 2011, at http://www.ars.usda.gov/SP2UserFiles/Place/64080530/ RUSLE/AH_703.pdf.

Robertson, D.M., and Saad, D.A., 2011, Nutrient inputs to the Laurentian Great Lakes by source and watershed estimated using SPARROW watershed models: Journal of the American Water Resources Association, DOI no. 10.1111/j.1752-1688.2011.00574.x. 
Schwarz, G.E., Hoos, A.B., Alexander, R.B., and Smith, R.A., 2006, The SPARROW surface water-quality model-Theory, application and user documentation: U.S. Geological Survey Techniques and Methods, book 6, section B, chap. 3 (online only), accessed March 22, 2011, at http://pubs.usgs.gov/tm/2006/tm6b3/.

Tonawanda Creek Watershed Committee, 2011, Tonawanda Creek Watershed: Tonawanda Creek Watershed Committee, accessed April 25, 2011, at http://www.wcswcd.org/images/ uploads/Tonawanda_Creek_Brochure.pdf.

U.S. Army Corps of Engineers, 2005, Great Lakes tributary modeling program - Status report: U.S. Army Corps of Engineers, 82 p., accessed March 30, 2011, at http://www. lrb.usace.army.mil/missions/516\%20fact.pdf.

U.S. Army Corps of Engineers, 2006, Great Lakes tributary modeling: U.S. Army Corps of Engineers, accessed December 3, 2010, at http://www.lrb.usace.army.mil/ missions $/ 516 \% 20$ fact.pdf.

U.S. Army Corps of Engineers, 2010, Great Lakes navigation: U.S. Army Corps of Engineers, accessed December 2, 2010, at http://www.lrd.usace.army.mil/navigation/glnavigation/.

U.S. Congress, 1996, Water resources development act of 1996: Public Law 104-303, 136 p., accessed February 4, 2011, at http://www.fws.gov/habitatconservation/Omnibus/ WRDA1996.pdf.

U.S. Department of Agriculture, 1986, Urban hydrology for small watersheds TR-55: U.S. Department of Agriculture, Natural Resources Conservation Service, Technical Release 55, 164 p., accessed May 19, 2011, at http://www.cpesc.org/ reference/tr55.pdf.

U.S. Department of Agriculture, 2010, Water erosion prediction project (WEPP): U.S. Department of Agriculture, Agricultural Research Service, National Soil Erosion Research Laboratory, accessed November 15, 2011, at http://www.ars.usda.gov/Research/docs.htm?docid=10621.

U.S. Department of Agriculture, 2011a, Soil and water assessment tool (SWAT): Temple, Tex., U.S. Department of Agriculture, Agricultural Research Service, Grassland, Soil and Water Research Laboratory, accessed February 4, 2011, at http://swatmodel.tamu.edu/.

U.S. Department of Agriculture, 2011b, Agricultural non-point source pollution model: U.S. Department of Agriculture, Natural Resources Conservation Service, accessed February 4, 2011, at http://www.wsi.nrcs.usda.gov/products/w2q/ h\&h/tools_models/agnps/index.html.
U.S. Environmental Protection Agency, 2010, Great Lakes areas of concern: U.S. Environmental Protection Agency, accessed December 1, 2010, at http://www.epa.gov/glnpo/ aoc/.

U.S. Environmental Protection Agency, 2011a, National hydrography dataset plus: U.S. Environmental Protection Agency, accessed May 24, 2011, at http://www.horizonsystems.com/nhdplus/.

U.S. Environmental Protection Agency, 2011b, Great Lakes areas of concern-Kalamazoo River area of concern: U.S. Environmental Protection Agency, accessed April 25, 2011, at http://www.epa.gov/glnpo/aoc/kalriv.html.

U.S. Geological Survey, 2010a, Great Lakes Restoration Initiative: U.S. Geological Survey, accessed December 1, 2010, at http://cida.usgs.gov/glri/.

U.S. Geological Survey, 2010b, SPARROW Surface waterquality modeling: U.S. Geological Survey, accessed November 15, 2010, at http://water.usgs.gov/nawqa/ sparrow/.

U.S. Geological Survey, 2011a, PRMS, Precipitation-runoff modeling system: U.S. Geological Survey, accessed March 22, 2011, at http://water.usgs.gov/software/PRMS/.

U.S. Geological Survey, 2011b, WATER-Water availability tool for environmental resources: U.S. Geological Survey, accessed April 13, 2011, at http://ky.water.usgs.gov/projects/ waterbudget/index.html.

Washington State University, 2011, Water erosion prediction project (WEPP): Washington State University, Department of Biological Systems Engineering, accessed May 19, 2011, at http://134.121.202.207/wepp/ [Login: weppwsu; password: nserl].

White House Council on Environmental Quality and others, 2010, Great Lakes Restoration Initiative Action Plan: 41 p., accessed December 1, 2010, at http://greatlakesrestoration. us/action/wp-content/uploads/glri_actionplan.pdf.

Williamson, T.N., Odom, K.R., Newson, J.K., Downs, A.C., Nelson Jr., H.L., Cinotto, P.J., and Ayers, M.A., 2009, The Water Availability Tool for Environmental Resources (WATER) - A water-budget modeling approach for managing water-supply resources in Kentucky — Phase I-Data processing, model development, and application to non-karst areas: U.S. Geological Survey Scientific Investigations Report 2009-5248, 34 p. 
Table 1. Tributaries to the Great Lakes, United States, with existing watershed models, U.S. Environmental Protection Agency Areas of Concern, and (or) U.S. Geological Survey water-quality monitoring sites for the Great Lakes Restoration Initiative, as of 2010.

[USACE, U.S. Army Corps of Engineers; NOAA, National Oceanic and Atmospheric Administration; GLERL, Great Lakes Environemtal Research Laboratory ; DLBRM, Distributed Large Basin Runoff Model; USEPA, U.S. Environmental Protection Agency; USGS, U.S. Geological Survey;

GLRI, Great Lakes Restoration Initiative; U, model under development; X, model exists or condition applies for given tributary; L, long-term, year-round monitoring for nutrients, sediment, chloride, and physical parameters; $\mathrm{O}$, one sample for anthropogenic contaminants, including pesticides, pharmaceuticals, personal-care products, wastewater-indicator compounds, and other organic compounds; HUC, hydrologic unit code; --, no data. State abbreviations: MN, Minnesota; WI, Wisconsin; MI, Michigan; IL, Illinois; IN, Indiana; OH, Ohio, PA, Pennsylvania; NY, New York]

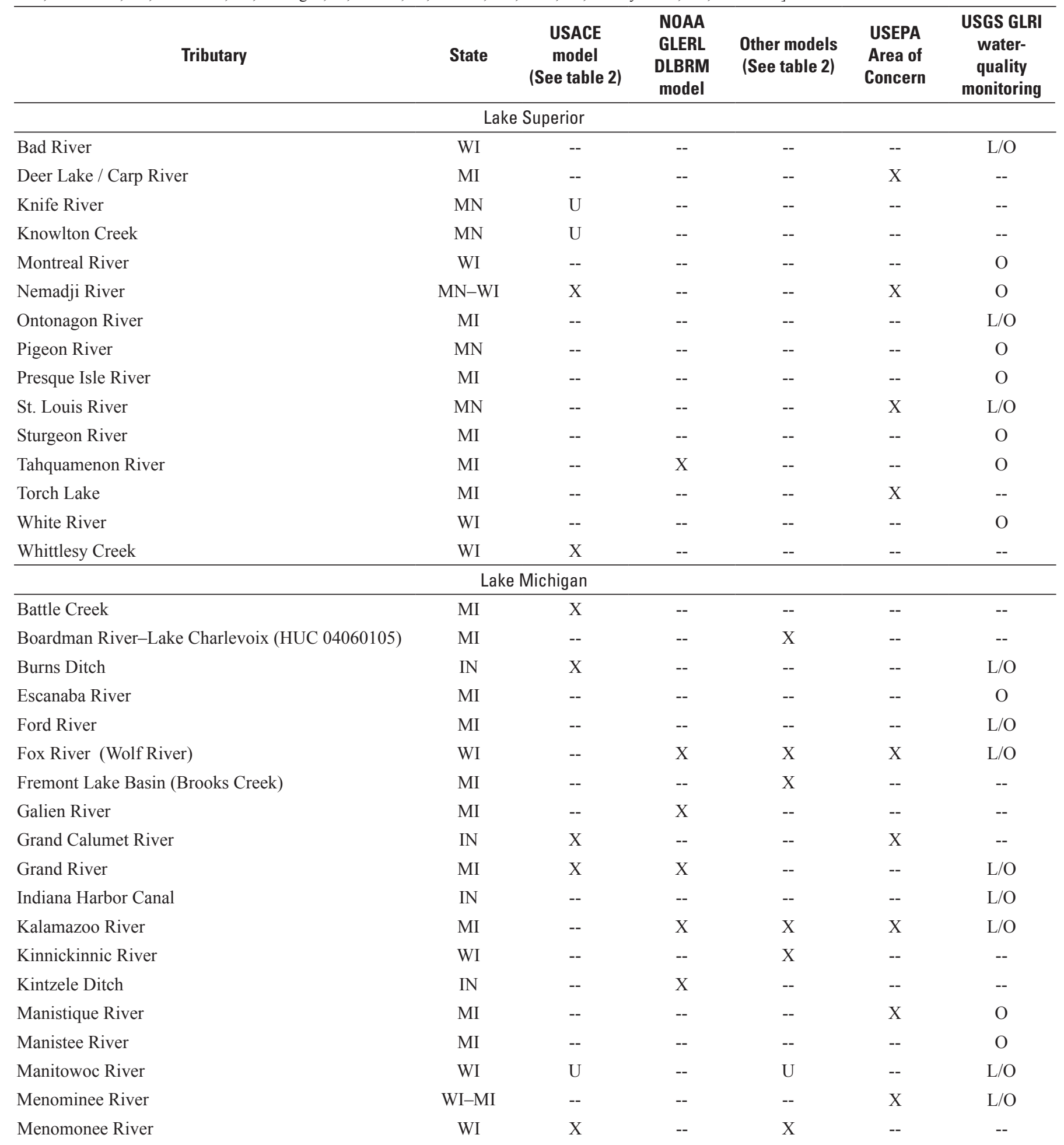


Table 1. Tributaries to the Great Lakes, United States, with existing watershed models, U.S. Environmental Protection Agency Areas of Concern, and (or) U.S. Geological Survey water-quality monitoring sites for the Great Lakes Restoration Initiative, as of 2010.

-Continued

[USACE, U.S. Army Corps of Engineers; NOAA, National Oceanic and Atmospheric Administration; GLERL, Great Lakes Environemtal Research Laboratory ; DLBRM, Distributed Large Basin Runoff Model; USEPA, U.S. Environmental Protection Agency; USGS, U.S. Geological Survey;

GLRI, Great Lakes Restoration Initiative; U, model under development; X, model exists or condition applies for given tributary; L, long-term, year-round monitoring for nutrients, sediment, chloride, and physical parameters; O, one sample for anthropogenic contaminants, including pesticides, pharmaceuticals, personal-care products, wastewater-indicator compounds, and other organic compounds; HUC, hydrologic unit code; --, no data. State abbreviations: MN, Minnesota; WI, Wisconsin; MI, Michigan; IL, Illinois; IN, Indiana; OH, Ohio, PA, Pennsylvania; NY, New York]

\begin{tabular}{|c|c|c|c|c|c|c|}
\hline Tributary & State & $\begin{array}{c}\text { USACE } \\
\text { model } \\
\text { (See table 2) }\end{array}$ & $\begin{array}{c}\text { NOAA } \\
\text { GLERL } \\
\text { DLBRM } \\
\text { model }\end{array}$ & $\begin{array}{l}\text { Other models } \\
\text { (See table 2) }\end{array}$ & $\begin{array}{l}\text { USEPA } \\
\text { Area of } \\
\text { Concern }\end{array}$ & $\begin{array}{c}\text { USGS GLRI } \\
\text { water- } \\
\text { quality } \\
\text { monitoring }\end{array}$ \\
\hline Milwaukee River & WI & -- & $\mathrm{X}$ & $X$ & $\mathrm{X}$ & $\mathrm{L} / \mathrm{O}$ \\
\hline Mona Lake Basin (Black Creek) & MI & -- & -- & $\mathrm{X}$ & -- & -- \\
\hline Muskegon River & MI & -- & $\mathrm{X}$ & $\mathrm{X}$ & -- & $\mathrm{L} / \mathrm{O}$ \\
\hline Oak Creek & WI & -- & -- & $\mathrm{X}$ & -- & -- \\
\hline Oconto River & WI & -- & -- & -- & -- & $\mathrm{O}$ \\
\hline Paw Paw River & MI & -- & -- & $\mathrm{X}$ & -- & $\mathrm{O}$ \\
\hline Root River & WI & -- & -- & $\mathrm{X}$ & -- & -- \\
\hline Sheboygan River & WI & -- & -- & -- & $\mathrm{X}$ & $\mathrm{O}$ \\
\hline Spring Lake Basin (Norris Creek) & MI & -- & -- & $X$ & -- & -- \\
\hline St. Joseph River & MI & $\mathrm{X}$ & $\mathrm{X}$ & $\mathrm{X}$ & -- & $\mathrm{L} / \mathrm{O}$ \\
\hline Trail Creek & IN & $\mathrm{X}$ & $\mathrm{X}$ & -- & -- & -- \\
\hline Waukegan River/Harbor & IL & $\mathrm{X}$ & -- & -- & $\mathrm{X}$ & -- \\
\hline White Lake & MI & -- & -- & -- & $\mathrm{X}$ & -- \\
\hline White River & MI & -- & -- & -- & -- & $\mathrm{O}$ \\
\hline \multicolumn{7}{|c|}{ Lake Huron } \\
\hline Kawkawlin-Pine Rivers (HUC 04080102) & MI & -- & $\mathrm{X}$ & $\mathrm{X}$ & -- & -- \\
\hline Pigeon-Wiscoggin Rivers (HUC 04080103) & MI & -- & $\mathrm{X}$ & $\mathrm{X}$ & -- & -- \\
\hline Pine River (HUC 04080202) & MI & -- & -- & $\mathrm{X}$ & -- & -- \\
\hline Rifle River & MI & -- & -- & -- & -- & $\mathrm{L} / \mathrm{O}$ \\
\hline Saginaw River & MI & $X$ & $\mathrm{X}$ & $X$ & $\mathrm{X}$ & $\mathrm{L} / \mathrm{O}$ \\
\hline Sebewaing River & MI & $\mathrm{X}$ & -- & -- & -- & -- \\
\hline Shiawassee River (HUC 04080203) & MI & -- & -- & $\mathrm{X}$ & -- & -- \\
\hline St. Marys River & MI & -- & -- & -- & $\mathrm{X}$ & -- \\
\hline Thunder Bay River & MI & -- & -- & -- & -- & $\mathrm{O}$ \\
\hline Tittabawassee River (HUC 04080201) & MI & -- & -- & $\mathrm{X}$ & -- & -- \\
\hline
\end{tabular}


Table 1. Tributaries to the Great Lakes, United States, with existing watershed models, U.S. Environmental Protection Agency Areas of Concern, and (or) U.S. Geological Survey water-quality monitoring sites for the Great Lakes Restoration Initiative, as of 2010.

-Continued

[USACE, U.S. Army Corps of Engineers; NOAA, National Oceanic and Atmospheric Administration; GLERL, Great Lakes Environemtal Research Laboratory ; DLBRM, Distributed Large Basin Runoff Model; USEPA, U.S. Environmental Protection Agency; USGS, U.S. Geological Survey;

GLRI, Great Lakes Restoration Initiative; U, model under development; X, model exists or condition applies for given tributary; L, long-term, year-round monitoring for nutrients, sediment, chloride, and physical parameters; $\mathrm{O}$, one sample for anthropogenic contaminants, including pesticides, pharmaceuticals, personal-care products, wastewater-indicator compounds, and other organic compounds; HUC, hydrologic unit code; --, no data. State abbreviations: MN, Minnesota; WI, Wisconsin; MI, Michigan; IL, Illinois; IN, Indiana; OH, Ohio, PA, Pennsylvania; NY, New York]

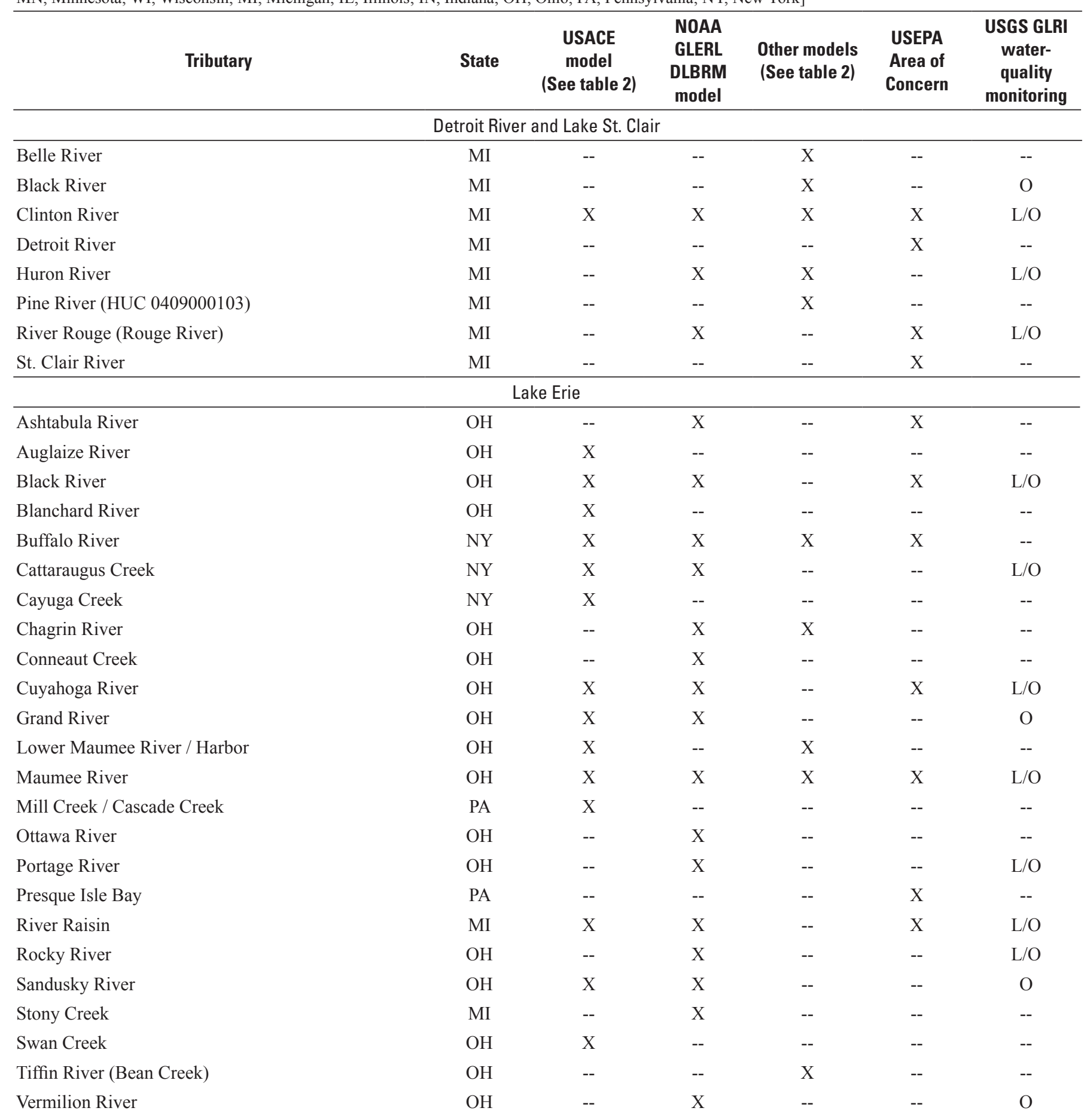


Table 1. Tributaries to the Great Lakes, United States, with existing watershed models, U.S. Environmental Protection Agency Areas of Concern, and (or) U.S. Geological Survey water-quality monitoring sites for the Great Lakes Restoration Initiative, as of 2010.

-Continued

[USACE, U.S. Army Corps of Engineers; NOAA, National Oceanic and Atmospheric Administration; GLERL, Great Lakes Environemtal Research Laboratory ; DLBRM, Distributed Large Basin Runoff Model; USEPA, U.S. Environmental Protection Agency; USGS, U.S. Geological Survey;

GLRI, Great Lakes Restoration Initiative; U, model under development; X, model exists or condition applies for given tributary; L, long-term, year-round monitoring for nutrients, sediment, chloride, and physical parameters; $\mathrm{O}$, one sample for anthropogenic contaminants, including pesticides, pharmaceuticals, personal-care products, wastewater-indicator compounds, and other organic compounds; HUC, hydrologic unit code; --, no data. State abbreviations: MN, Minnesota; WI, Wisconsin; MI, Michigan; IL, Illinois; IN, Indiana; OH, Ohio, PA, Pennsylvania; NY, New York]

\begin{tabular}{|c|c|c|c|c|c|c|}
\hline Tributary & State & $\begin{array}{c}\text { USACE } \\
\text { model } \\
\text { (See table 2) }\end{array}$ & $\begin{array}{c}\text { NOAA } \\
\text { GLERL } \\
\text { DLBRM } \\
\text { model }\end{array}$ & $\begin{array}{l}\text { Other models } \\
\text { (See table 2) }\end{array}$ & $\begin{array}{l}\text { USEPA } \\
\text { Area of } \\
\text { Concern }\end{array}$ & $\begin{array}{c}\text { USGS GLRI } \\
\text { water- } \\
\text { quality } \\
\text { monitoring }\end{array}$ \\
\hline \multicolumn{7}{|c|}{ Lake Ontario and St. Lawrence River } \\
\hline Black River & NY & -- & -- & -- & -- & $\mathrm{O}$ \\
\hline Eighteenmile Creek & NY & $\mathrm{X}$ & -- & -- & $\mathrm{X}$ & -- \\
\hline Genesee River & NY & $\mathrm{X}$ & $\mathrm{X}$ & $\mathrm{X}$ & $\mathrm{X}$ & $\mathrm{L} / \mathrm{O}$ \\
\hline Grass River & NY & -- & -- & -- & -- & $\mathrm{O}$ \\
\hline Irondequoit Creek & NY & -- & -- & $\mathrm{X}$ & -- & -- \\
\hline Niagara River & NY & -- & -- & -- & $\mathrm{X}$ & -- \\
\hline Oak Orchard Creek & NY & $\mathrm{X}$ & -- & -- & -- & -- \\
\hline Onondaga Lake Basin & NY & -- & -- & $\mathrm{x}$ & -- & -- \\
\hline Oswegatchie River & NY & -- & -- & -- & -- & $\mathrm{O}$ \\
\hline Oswego River & NY & -- & -- & -- & delisted & $\mathrm{L} / \mathrm{O}$ \\
\hline Raquette River & NY & -- & -- & -- & -- & $\mathrm{O}$ \\
\hline St. Lawrence River at Massena & NY & -- & -- & -- & $\mathrm{X}$ & -- \\
\hline St. Regis River & NY & -- & -- & -- & -- & $\mathrm{L} / \mathrm{O}$ \\
\hline Tonawanda Creek & NY & -- & -- & -- & -- & $\mathrm{O}$ \\
\hline
\end{tabular}




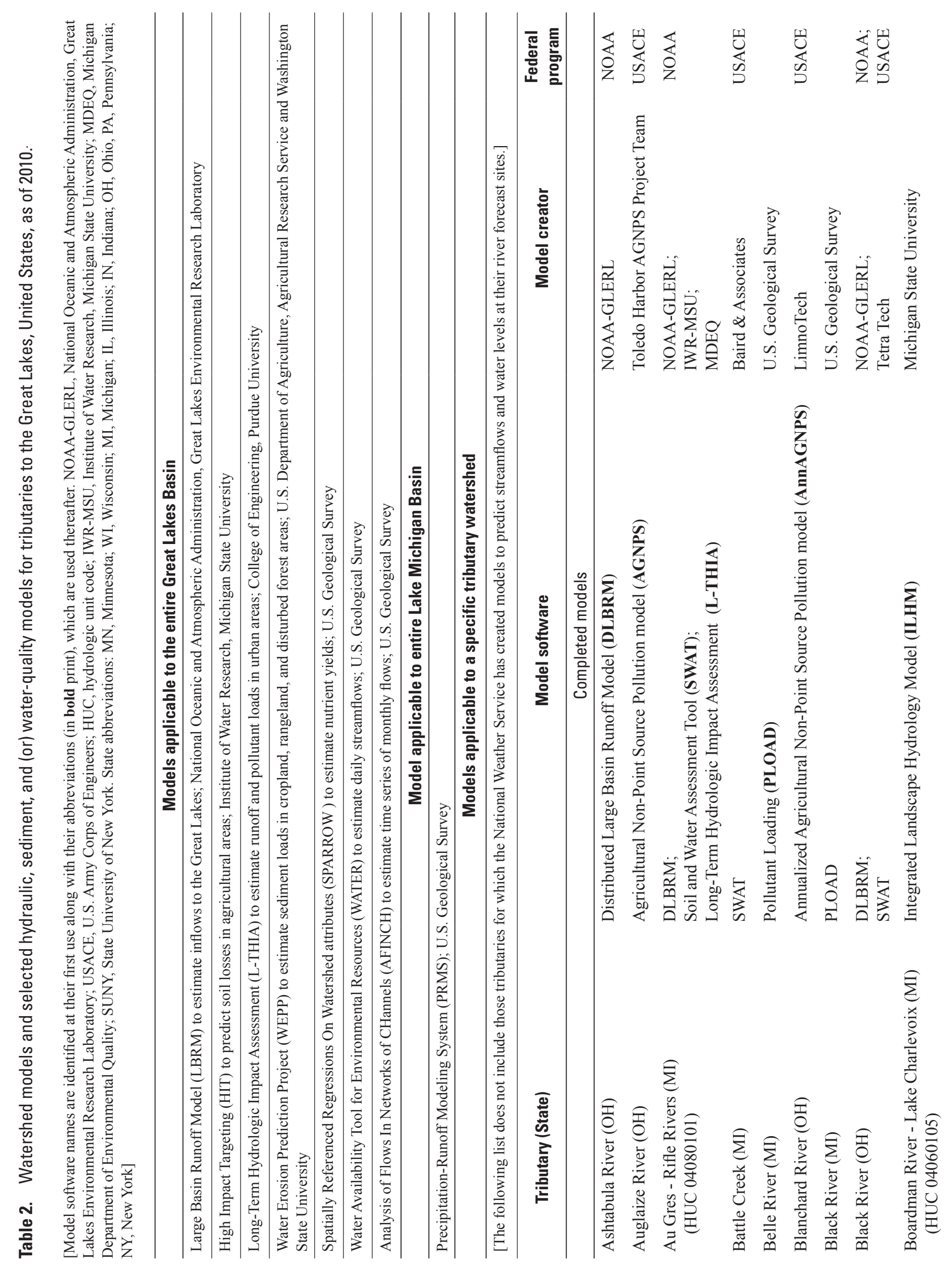




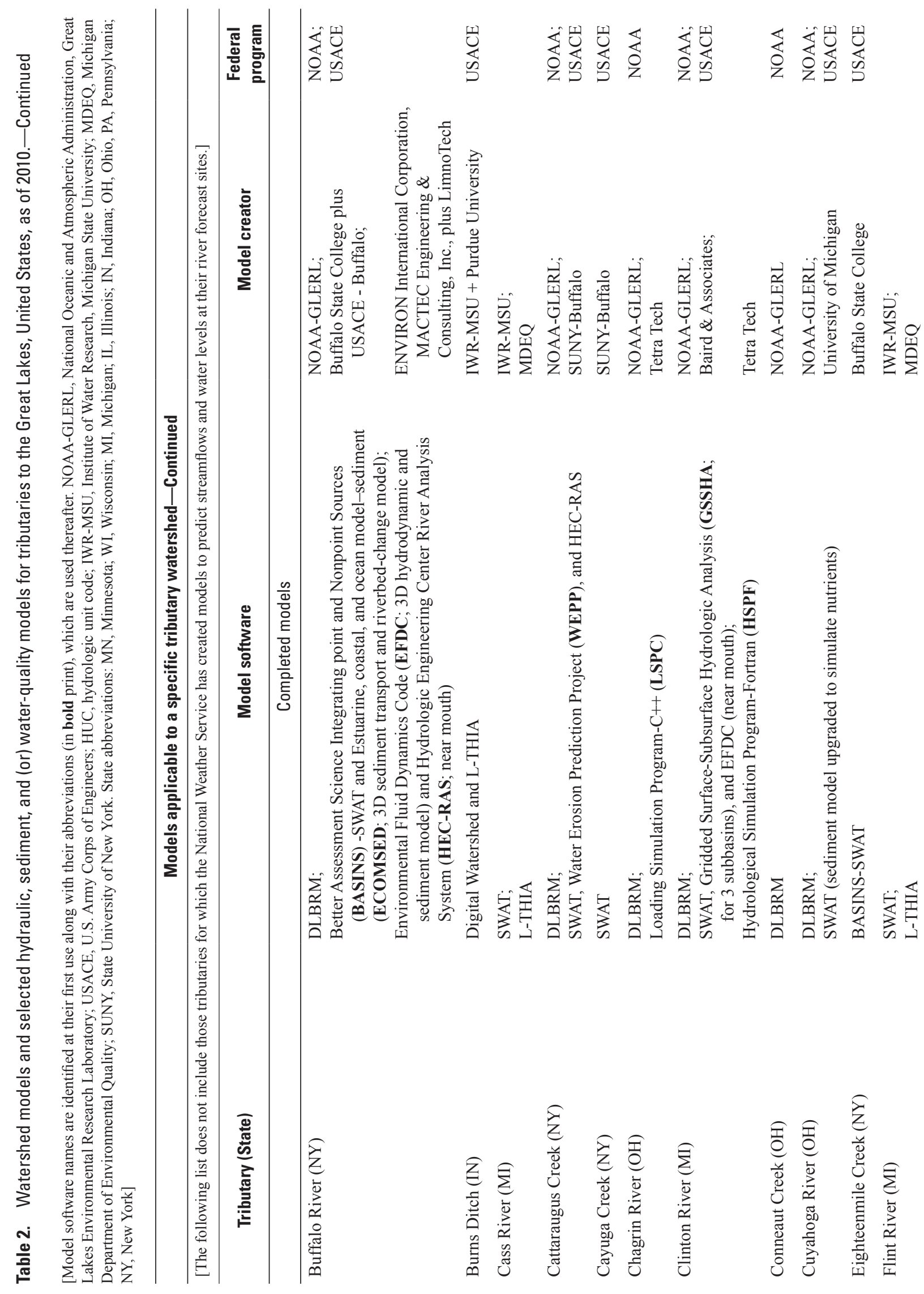




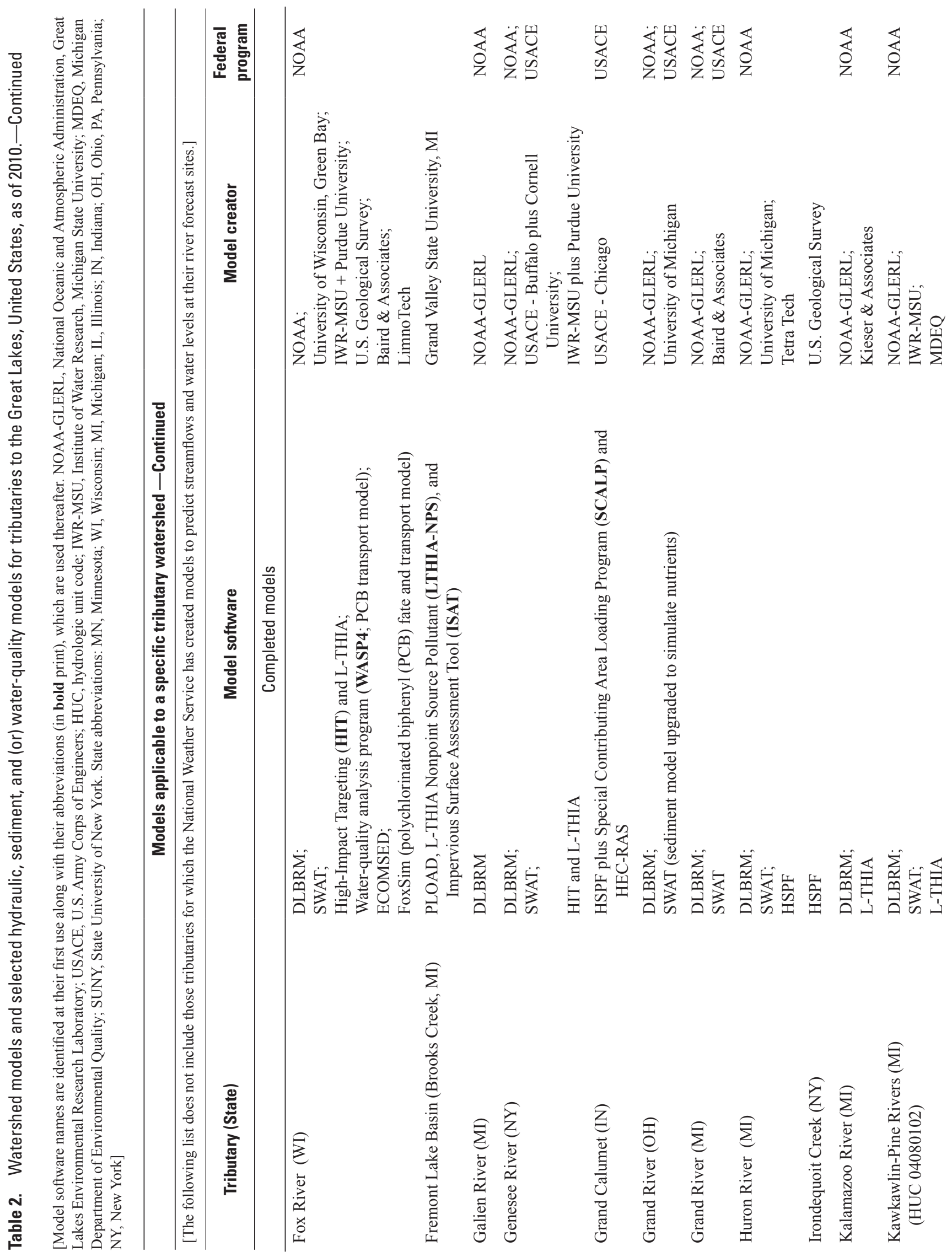




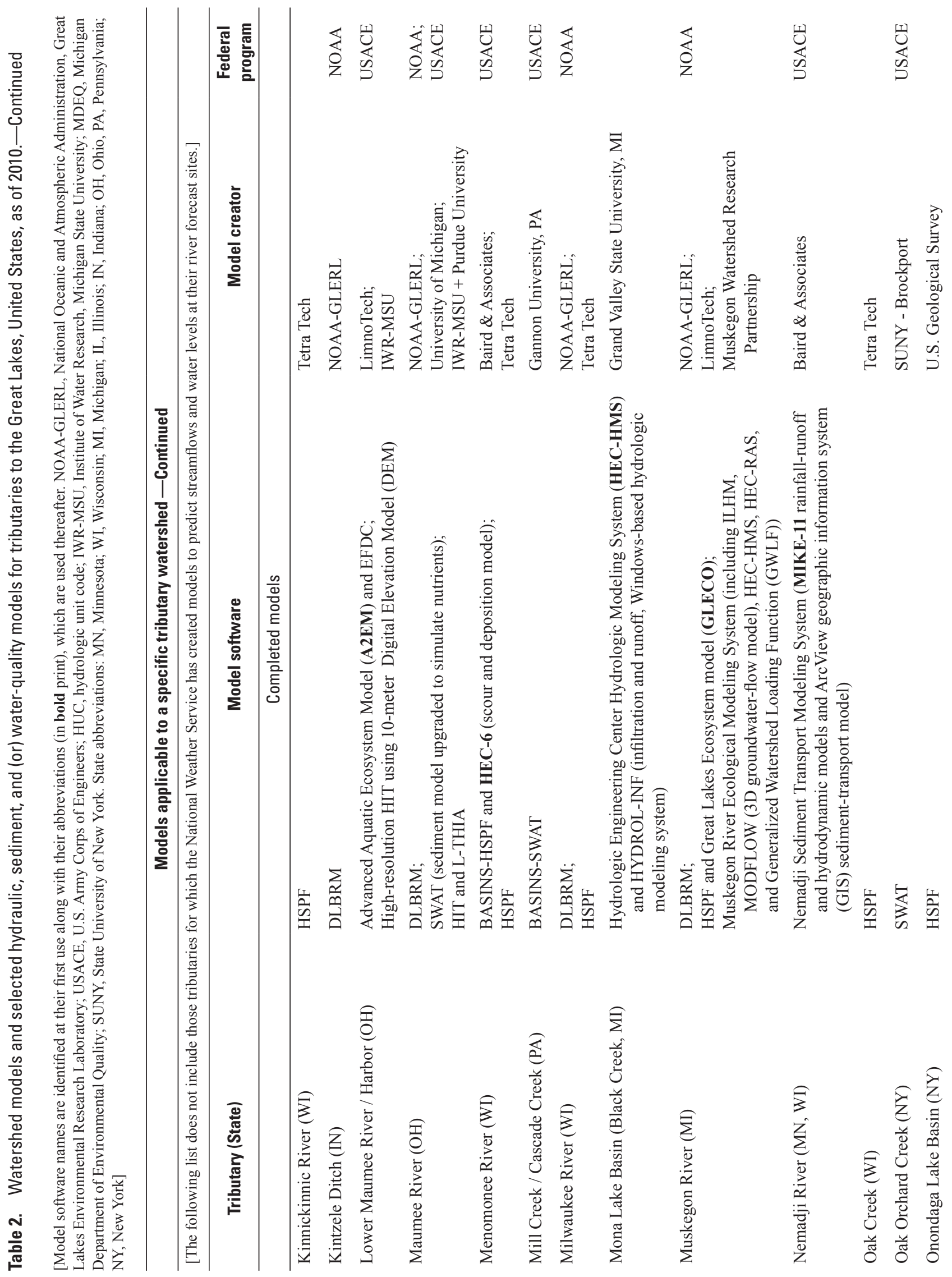




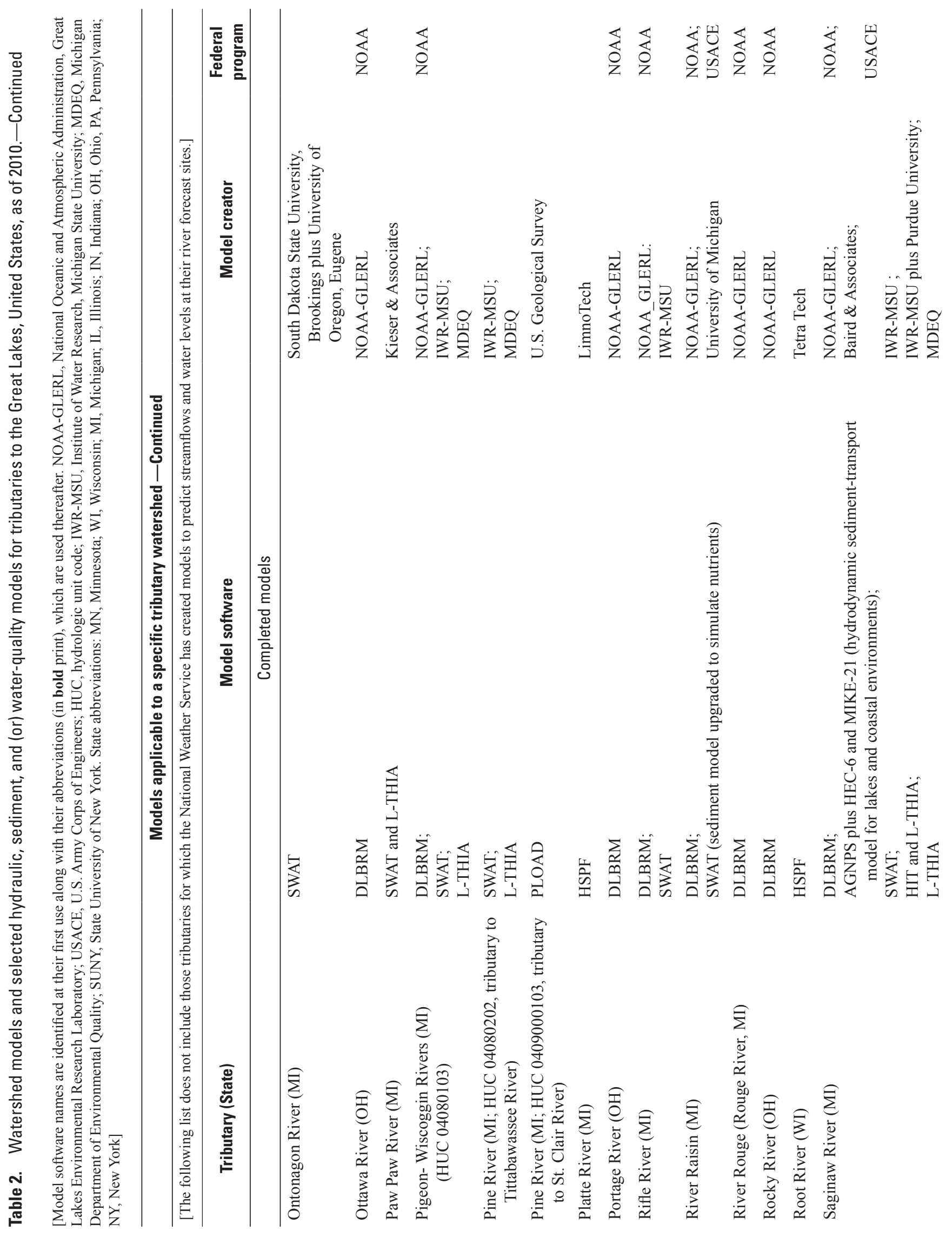


Table 2

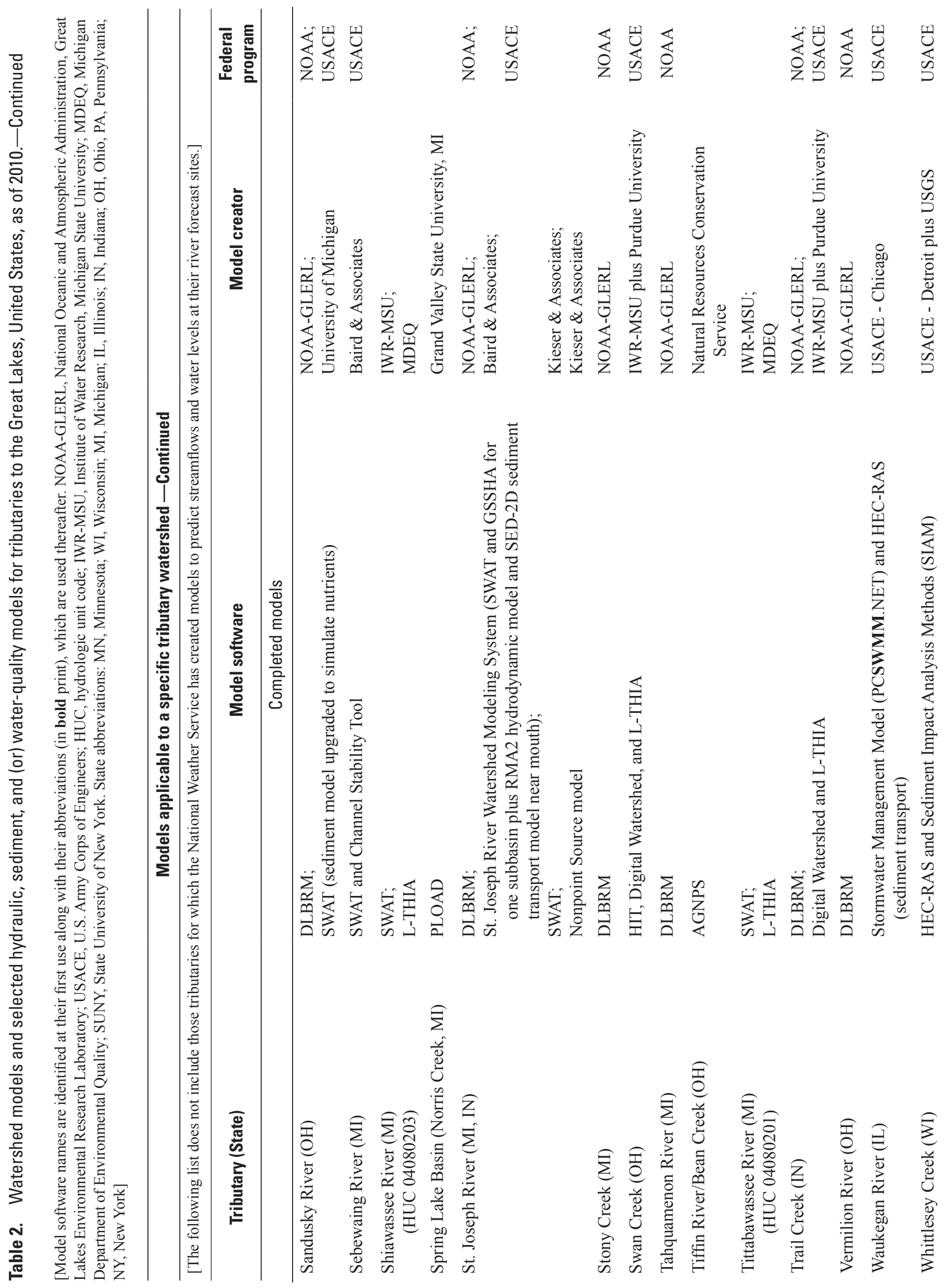




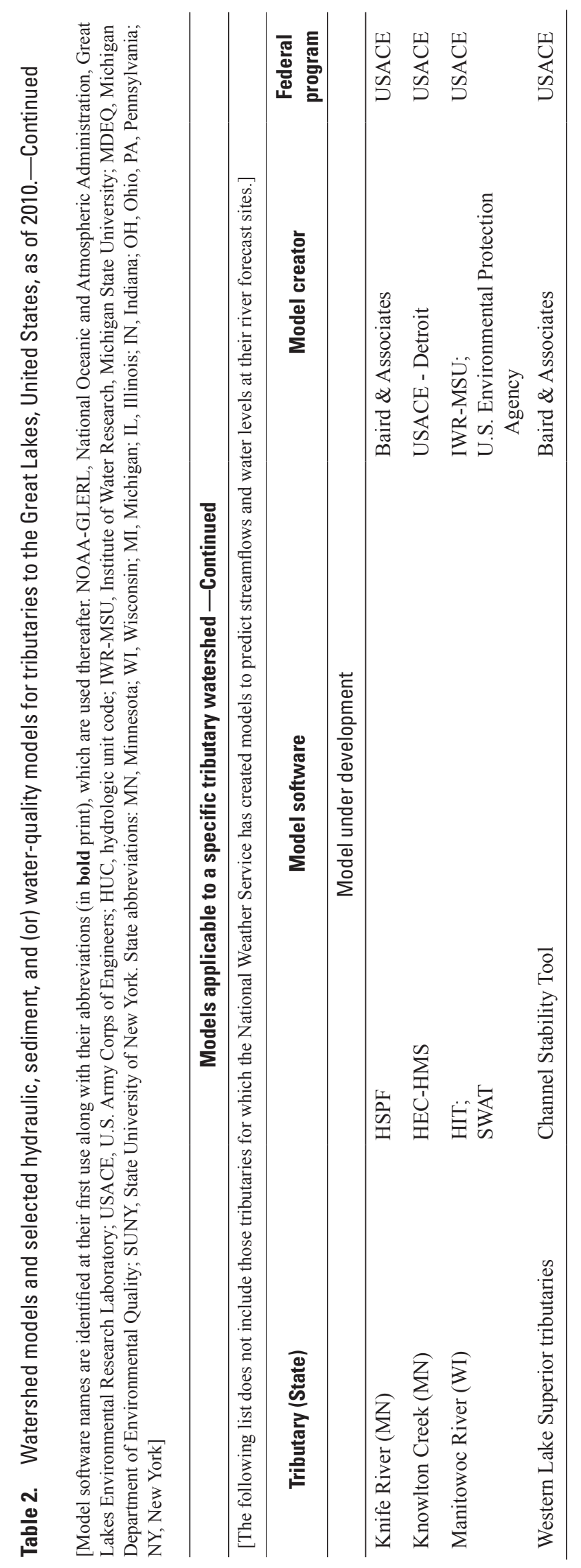



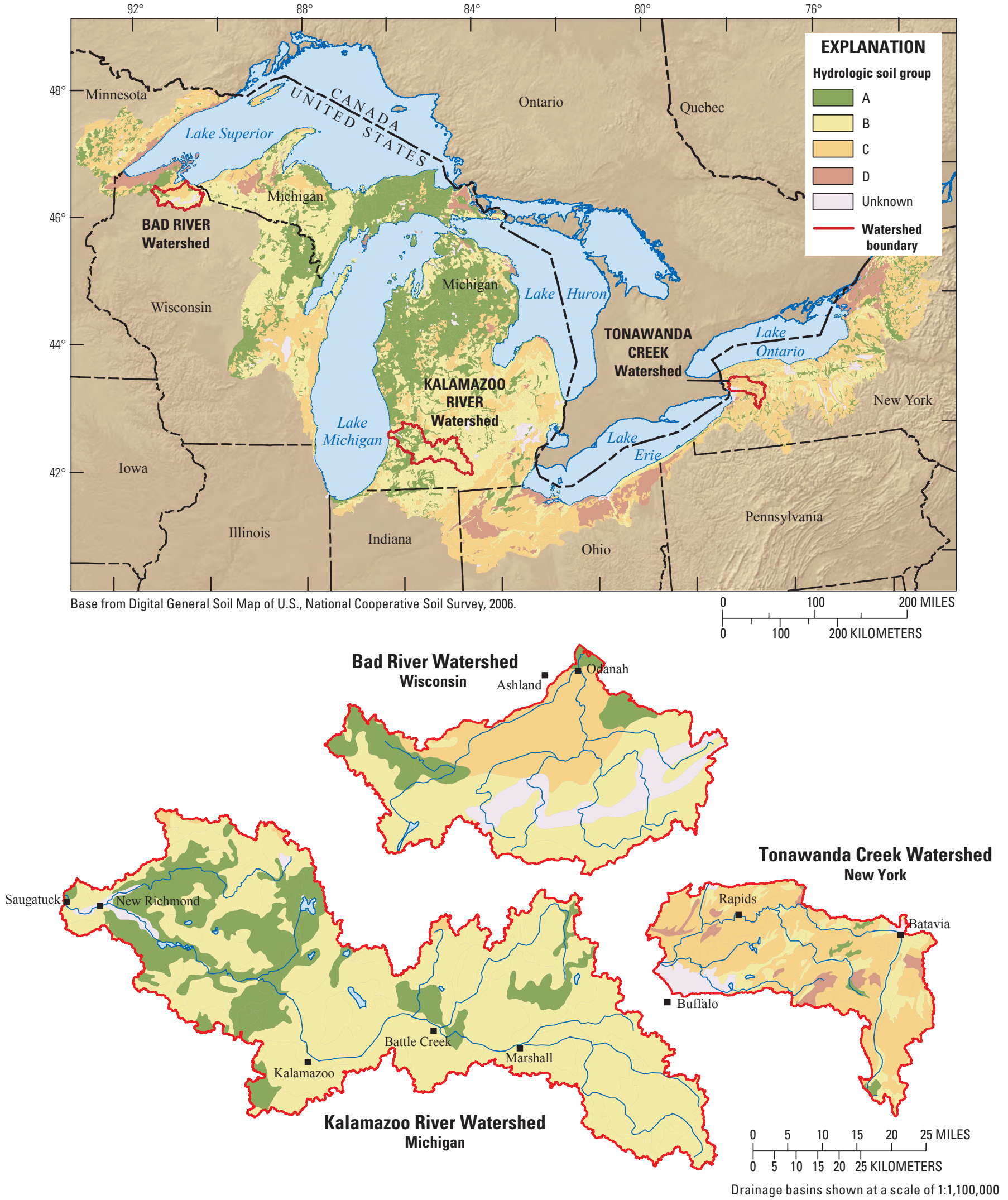

Figure 1. Hydrologic soil groups of the Great Lakes Basin, United States, and three tributary watersheds identified for modeling. 


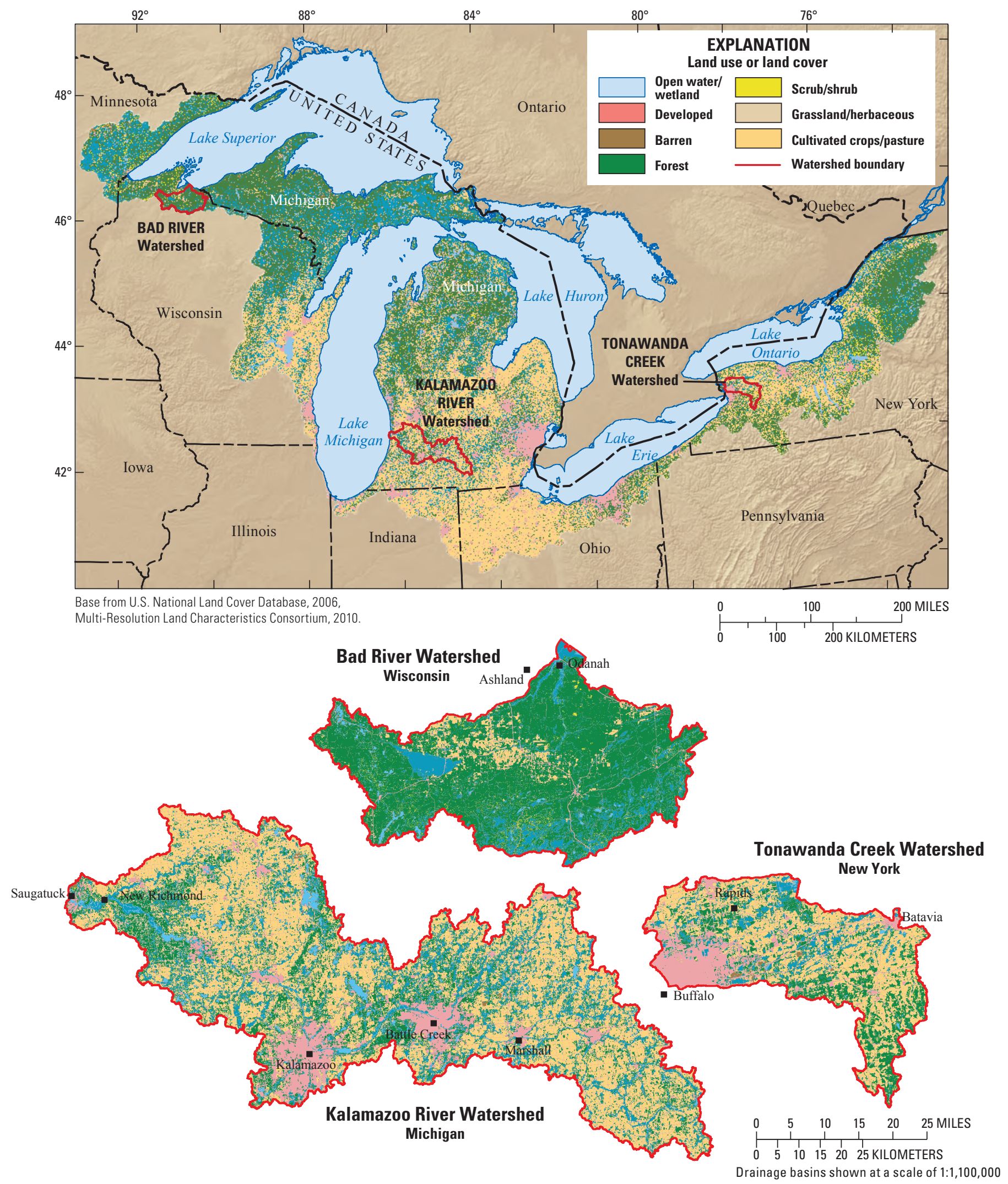

Figure 2. Land uses and land covers of the Great Lakes Basin, United States, and three tributary watersheds identified for modeling. 


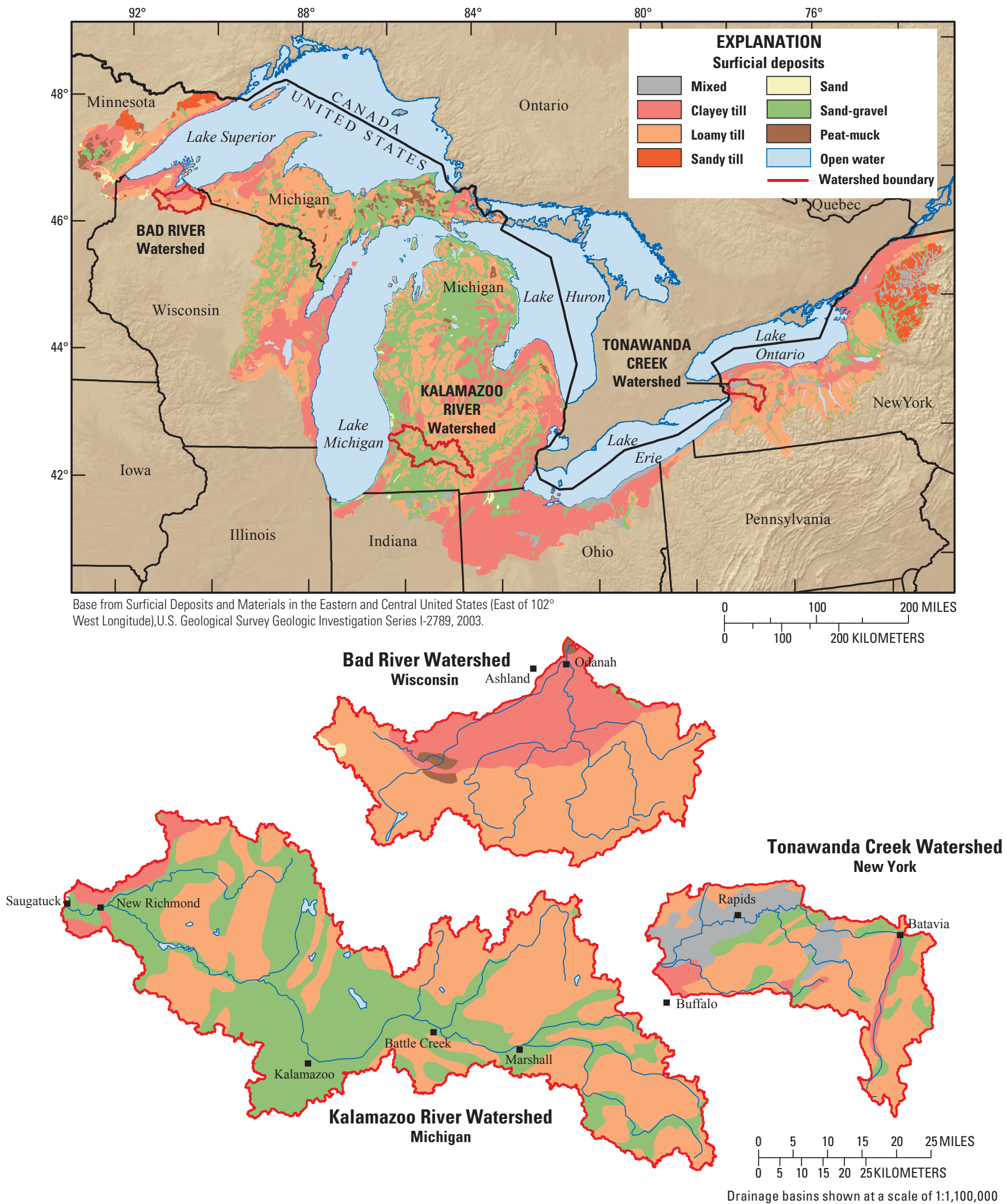

Figure 3. Surficial deposits of the Great Lakes Basin, United States, and three tributary watersheds identified for modeling. 
This page has been left blank intenttionally 
Prepared by the Pembroke and West Trenton Publishing Service Centers.

For additional information write to:

New York Water Science Center

U.S. Geological Survey

30 Brown Rd.

Ithaca, NY 14850

Information requests:

(518) 285-5602

or visit our Web site at: http://ny.water.usgs.gov 


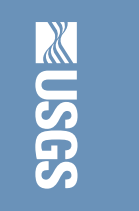

$\S$

言

产 